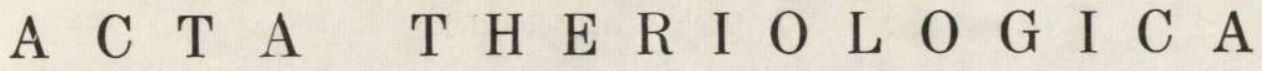

VOL. 18, 10: 201-207

BIAEOWIEŻA

August, 1973

Ewa B OCK* \& Anna KOŁODZIE J

\section{Estimation of Fatness of Common Vole by the Method of Collective Sample**}

[With 2 Tables and 2 Figs.]

The subject of the study concerned estimation of usefulness of two methods: a) specific weight, b) collective extraction - for the determination of fat contents in the organism of a large number of voles, Microtus arvalis. It was demonstrated that the method of estimation of fatness based on the specific weight is not suitable for the studies with Microtus arvalis. On the other hand, the method of collective extraction, i.e. fat extraction of groups of individuals in appropriate classes of weight and sex provides a reliable information on the order of magnitude of body fatness in a given population. Mathematical analysis demonstrated that in order of determining the body fatness of a group of voles at least 20 individuals should be used for the investigations. A number of samples higher than 20 permits for even more accurate determination of fat contents.

\section{INTRODUCTION}

N a u mov (1953), when analysing the causes of mass occurrence of Microtus arvalis ( $\mathrm{P}$ allas, 1779), suggested that among other factors body fatness of these animals in the autumn-winter period is very important. The voles with a higher fat content are more resistant to the effects of environment and due to this show a higher survival rate. Hence it can be stated that fatness affects to a certain degree the numbers of population in spring.

In order to use these data in the prognosing of population numbers of voles the changes in the fat content in the organism of free-living voles

* Present address: Department of Bioenergetics and Bioproductivity, Nencki Institute of Experimental Biology, Pasteura 3, 02-093 Warszawa, Poland.

** Badania były prowadzone w ramach problemu węzłowego 09.1.7., koordynowanego przez Instytut Ekologii PAN. 
should be determined in the year cycle. Then this should be correlated with population numbers in a many-years period.

This study was aimed at finding a method enabling quick and rather accurate estimation of fat contents in the organism of a large number of voles.

\section{MATERIAL AND METHODS}

The subject of this study concerned estimation of usefulness of two methods: a) specific weight, b) collective extraction of fat from a group of animals.

M. arvalis deriving from alfa-alfa fields was the object of the study. The animals were captured by the method of flooding (Andrzejewski \& Gliwi c z, 1969).

The material was collected in October 1971. It derived from three different localities: sample A -82 individuals, sample B -62 individuals, and sample C -29 individuals.

\subsection{Method of Specific Weight}

In order to determine the specific weight the bodies of voles were weighed at first in air and then in alcohol. From the ratio of weight in air to the difference of weight in air and alcohol the value of specific weight was calculated. B o n d arenko \& Krivonosov (1962) used water instead of alcohol in the studies of bank vole. In the case of field voles water could not be used because the animals did not submerge in it.

In order to control the usefulness of this method for the estimation of voles fatness the following experiment was carried out. 26 field voles captured in a free-living population in Łomna near Warszawa were kept for 10 days on the diet consisting of green forage, sunflower seeds and water. The food was always supplied in an excess. After 10 days 11 individuals showing the highest weight were selected, killed, and the specific weight of their bodies was determined. Then fatness of these animals was determined by the method of extraction. The remaining 14 voles were fasted for next 10 days being supplied with water and apple only. Then they were treated in a manner similar to the first group. After killing, weighing and opening the abdominal cavity the bodies were dried at $70^{\circ} \mathrm{C}$ to a constant weight. The dried carcasses were ground in an electric grinder. The powder was kept in glass vessels equipped with polished stoppers. Before the extraction the vessel content was shaken and mixed in a mechanical device to obtain a homogenous material. Then a sample weighing approximately $1.5 \mathrm{~g}$ was removed and placed in an extraction vessel with porous bottom. The vessel was put into an oven at $70^{\circ} \mathrm{C}$ for $2 \mathrm{hr}$ and later transferred to a desiccator with calcium carbonate for $30 \mathrm{~min}$. The weight of the dried sample was accurately determined and used for further calculations of fat contents in the dry matter. The extraction was carried out with petroleum ether by the method of Puzanov \& Badun ard Hannon \& Besson ( $\mathrm{Krauze}$ et al., 1966) for 3.5 to 4 hours from the moment of beginning of ether boiling. This period was sufficient for the total extraction of fat (M y cha, 1969). Fresh ether was used for each extraction. Two samples of dry matter from each vole were analyzed. The arithmetic mean of the determinations was assumed as fatness of a given animal. 
The mean fatness of fat animals amounted to $46.6 \%$ dry matter, and lean animals to $26.8 \%$. The difference in the fat contents between these two groups is statistically significant $\left(t=2.59 ; t_{0.05}=2.07\right)$. For all individuals the correlation coefficient between fat contents and specific weight was calculated (Fig. 1) and the lack of relationship between these two values was ascertained. The coefficient of correlation $(r=0.085)$ is statistically not significant. This means that the method of estimation of fat contents on the basis of specific weight is not suitable for the application in the studies with $M$. arvalis.

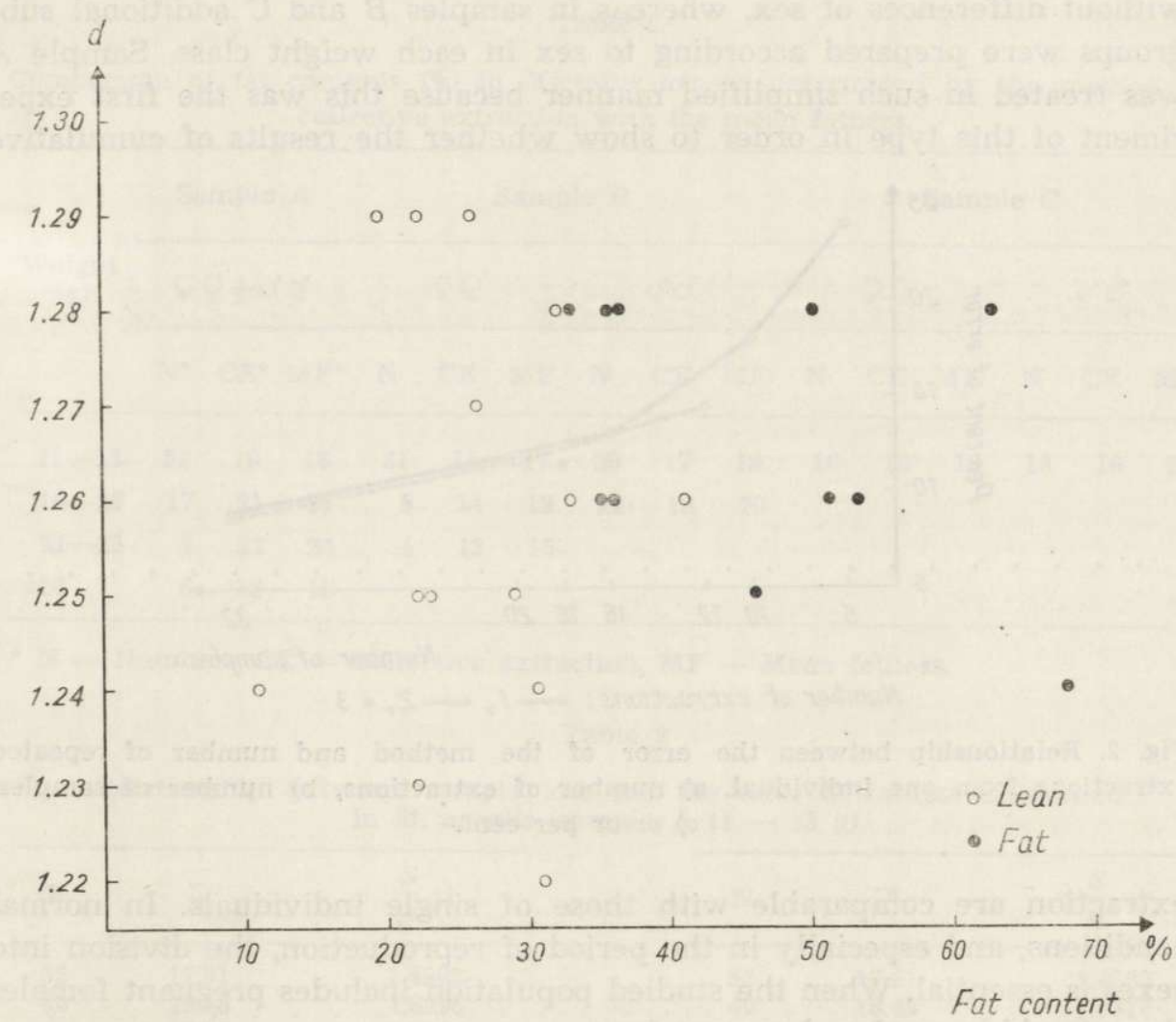

Fig. 1. Relationship between specific weight (d) and fat contents (\%) a) lean, b) fat, c) \% of fat.

\subsection{Method of Collective Extraction}

Taking into consideration the fact that extraction of single individuals of $M$. arvalis is very time-consuming and hence of limited value for the analysis of a large material, the collective extraction was employed for a definite group of animals. The selected animals were killed and their 
eye-lenses, thyroids, kidneys, adrenals and intestine tracts were removed (for other investigations), while the livers remained in situ. The animals were weighed before removal of the intestine tract. According to the determined weight the voles were divided into weight classes at $5 \mathrm{~g}$ intervals. For each group 3 extractions by Puzanov method were carried out.

The investigated material derived from three various localities in Poland, which were denoted as samples $A, B$, and $C$. In sample $A$ the powdered dry matter from voles of appropriate weight classes was mixed without differences of sex, whereas in samples $B$ and $C$ additional subgroups were prepared according to sex in each weight class. Sample $A$ was treated in such simplified manner because this was the first experiment of this type in order to show whether the results of cumulative

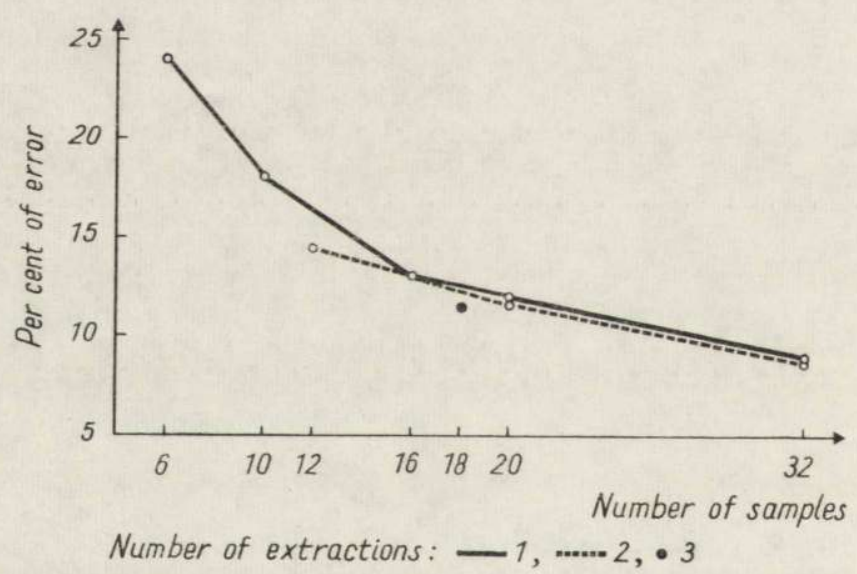

Fig. 2. Relationship between the error of the method and number of repeated extractions from one individual. a) number of extractions, b) number of samples, c) error per cent.

extraction are comparable with those of single individuals. In normal conditions, and especially in the period of reproduction, the division into sexes is essential. When the studied population includes pregnant females they should be analysed separately.

Before mixing of samples in particular weight classes $1.5 \mathrm{~g}$ samples from each individuals were left. This allowed to compare the results of cumulative extraction with extraction of single individuals, for which only one extraction was carried out.

In order to determine the error of the extraction method the fat content in one animal was compared after one, two or three repeated extractions. The per cent of error for a given number of samples and given number of animals was calculated as the ratio of half confidence 
interval (at $\alpha=0.05$ ) to the mean percentage of fat content. The results are shown in Fig. 2, from which it appears that the error per cent for the curve obtained from single extraction (1) begins to overlap the curve for two extractions (2) at the number of samples equal to 16 and error of the method equal to $13 \%$. This range of error in our investigations is small. Hence it arises that in our studies the results of single extraction can be taken into consideration assuming that subsequent analysis will include a group not smaller that 16 individuals.

Table 1

Comparison of fat contents (\%) in Microtus arvalis determined by the method of collective extraction with the mean fatness.

\begin{tabular}{|c|c|c|c|c|c|c|c|c|c|c|c|c|c|c|c|}
\hline \multirow{3}{*}{$\begin{array}{l}\text { Weight } \\
\text { (g) }\end{array}$} & \multirow{2}{*}{\multicolumn{3}{|c|}{$\begin{array}{l}\text { Sample } A \\
\text { ᄋி+ }+0^{*} \sigma^{*}\end{array}$}} & \multicolumn{6}{|c|}{ Sample $B$} & \multicolumn{6}{|c|}{ Sample $C$} \\
\hline & & & & & 우 & & & $0^{\prime \prime} 0^{\circ}$ & & & 우우 & & & $0^{\circ} 0^{\circ}$ & \\
\hline & $\mathrm{N}^{*}$ & $\mathrm{CE}^{*}$ & $\mathrm{MF}^{*}$ & $\mathrm{~N}$ & $\mathrm{CE}$ & MF & $\mathrm{N}$ & $\mathrm{CE}$ & MF & $\mathrm{N}$ & $\mathrm{CE}$ & MF & $\mathrm{N}$ & $\mathrm{CE}$ & MF \\
\hline $11-15$ & 52 & 19 & 18 & 21 & 15 & 17 & 20 & 17 & 19 & 16 & 18 & 18 & 13 & 16 & 16 \\
\hline $16-20$ & 17 & 21 & 21 & 5 & 14 & 18 & 12 & 18 & 20 & & & & & & \\
\hline $21-25$ & 7 & 22 & 24 & 4 & 13 & 15 & & & & & & & & & \\
\hline 26 & 6 & 18 & 18 & & & & & & & & & & & & \\
\hline
\end{tabular}

* $\mathrm{N}-$ Numbers, $\mathrm{CE}-$ Collective extraction, $\mathrm{MF}$ - Mean fatness.

Table 2

Relationship between sample size and the error of fatness estimation in $M$. arvalis (sample $A 11-15 \mathrm{~g}$ ).

\begin{tabular}{rcc}
\hline $\mathrm{N}$ & $\overline{\mathrm{x}}$ & $\frac{S}{N} \cdot t$ \\
\hline 52 & 17.91 & 1.4982 \\
40 & 18.58 & 1.8293 \\
30 & 18.85 & 2.3285 \\
20 & 17.11 & 2,3723 \\
10 & 17.36 & 3.2329 \\
5 & 15.45 & 4.7818 \\
\hline
\end{tabular}

\begin{tabular}{ccc}
\hline $\mathrm{N}$ & $\overline{\mathrm{x}}^{*}$ & $\frac{S}{N} \cdot t^{*}$ \\
\hline 52 & 17.91 & 1.4982 \\
40 & 18.48 & 1.8314 \\
30 & 18.05 & 1.7450 \\
20 & 17.31 & 2.5108 \\
10 & 20.08 & 4.2882 \\
5 & 20.23 & 10.2342 \\
\hline
\end{tabular}

* Values selected with the use of tables of random numbers.

The results obtained by the extraction of single individuals were added up and the arithmetic mean was calculated. This provided information on the mean fat contents in a given weight class. The arithmetic mean was compared with the value of fatness obtained from cumulative extracActa theriol. 14 
tion (Table 1). By employing the method of collective extraction a considerable degree of agreement between mean body fatness and the value obtained from single extraction was obtained for samples $A$ and $C$. In order to determine the minimum number of samples the arithmetic mean of vole fatness was calculated, as well as the confidence interval for this mean taking consecutively $5,10,20,30,40$ and 52 samples. These samples were selected with the use of tables of random numbers from sample $A$ containing 52 individuals. The confidence intervals were calculated at the level of significance $\alpha=0.05$. The obtained results (Table 2) permit to conclude that in order to determine vole fatness at least 20 samples should be analysed. A number of samples exceeding 20 permits to determine much more accurately the fat content.

\section{DISCUSSION}

Small differences between the results obtained by the method of collective extraction, and those from single extractions may be due to a considerable variability of fatness obtained by single extractions, as reflected in the mean. In sample $B$ these differences are the most evident, perhaps on account of a smaller number of individuals in particular weight classes. The obtained results are encumbered with some error since not in all cases a mixture of dry matter was prepared from more than 20 individuals. It seems however, that for analysing a large material the method of collective extraction can be employed, because, despite the errors resulting from the difficulties of obtaining ideally homogenous material, it gives a reliable information on the order of magnitude of fatness in a given population.

\section{REFERENCES}

1. Andrzejewski R. \& Gliwicz J., 1969: Standard method of density estimation of Microtus arvalis ( $\mathrm{P}$ a 11 a s, 1779) for the investigation on its productivity. Small Mammal Newslett. 3, 2: 45- 53.

2. Bondarenko A. D. \& Krivonosov L. K. A., 1962: K metodike opredelenija upitannosti gryzunov po ih udel'nomu vesu. Pervoe vsesojuznoe soveščanie po mlekopitajuščim 25-31 Janvarja 1962 g. Tezisy dokladov II. Izd. mosk. Univ.: 13.

3. Krauze S., Bożyk Z. \& Piekarski L., 1966: Podręcznik laboratoryjny analityka żywnościowego. Państw. Zakł. Wyd. Lek.: 1-588. Warszawa.

4. Na umov N. P., 1953: Dinamika čislennosti obyknovennoj polevki (Microtus arvalis $\mathrm{P}$ a 11.) i metody prognozov $\mathrm{v}$ srednej SSSR. Zool. Ž. 32, 2: 300-311.

5. Myrcha A., 1969: Seasonal changes in caloric value, body water and fat in some shrews. Acta theriol., 14, 16: 211-227.

Accepted, March 20, 1973. 
Ewa BOCK i Anna KO£ODZIEJ

\section{OCENA OTŁUSZCZENIA MICROTUS ARVALIS (PALLAS, 1779) METODĄ PRÓBY ZBIORCZEJ}

\section{Streszczenie}

Przedmiotem pracy była ocena przydatności dwóch metod: a) ciężaru właściwego, b) ekstrakcji zbiorczej dla określenia otłuszczenia dużej liczby norników.

W celu uzyskania ciężaru właściwego ważono zwierzęta najpierw w powietrzu, a potem w alkoholu. Ze stosunku ciężaru w powietrzu do różnicy ciężaru w powietrzu i alkoholu wyliczono ciężar właściwy. Przeprowadzono doświadczenie na 25 nornikach. Po zabiciu oznaczono ich ciężar właściwy, a potem badano otłuszczenie metodą ekstrakcji. Wykazano brak zależności między ciężarem właściwym norników a ich otłuszczeniem (Fig. 1). Współczynnik korelacji jest statystycznie nieistotny $r=0,085 ; r_{0,05}=0,38$. Zatem metoda ciężaru właściwego nie nadaje się do badań nad $M$. arvalis.

Metodą ekstrakcji zbiorczej, tzn. ekstrakcji grup osobników w odpowiednich klasach ciężaru i ze zróżnicowaniem na płcie, oceniano zawartość tłuszczu dla trzech grup zwierząt: próba $A-82$ osobniki, próba $B-62$ osobniki, próba $C-29$ osobników. Podziału na klasy dokonywano w oparciu o ciężar zwierzęcia zaraz po zabiciu. Rozpiętość ciężaru w klasach wynosiła $5 \mathrm{~g}$.

Przed zmieszaniem proszku z norników w poszczególnych klasach ciężaru zbadano zawartość tłuszczu w każdym zwierzęciu, w oparciu o ekstrakcję pojedynczej próbki z każdego osobnika. Srednie otłuszczenie zwierząt w klasach ciężaru, będące średnią arytmetyczną wyników uzyskanych z ekstrakcji pojedynczych osobników, porównywano $\mathrm{z}$ wynikami ekstrakcji zbiorczych $\mathrm{w}$ tych samych klasach ciężaru (Tabela 1).

Analiza matematyczna wykazała, że należy wziąć minimum 20 prób do ekstrakcji zbiorczej, aby wynik informował nas dobrze o zawartości tłuszczu w badanej grupie norników (Tab. 2; Fig. 3).

Institute of Ecology,

Polish Academy of Sciences,

Dziekanów Leśny, 05-150 Łomianki, Poland. 